\title{
Chapter 14 \\ The Avifauna of Angola: Richness, Endemism and Rarity
}

\author{
W. Richard J. Dean, Martim Melo, and Michael S. L. Mills
}

\begin{abstract}
Angola has a rich history of ornithological exploration going back to the early 1800s. From the early-1970s to 2002, however, the civil war prevented access to many areas, and very little work on birds was done. From about the early 2000s information on birds in Angola has been gathered at an increasing rate, with new species being added to the list and a steady rise in publications on biogeography and biology of birds. With about 940 species, Angola has an impressive array of bird species, including c. 29 endemic species, and several species that are rare and poorly known. For the future, there are many areas of avian biology to attract studies, not only to gather more data on the rare and endemic species, but also local surveys of bird communities, the identification of major threats to the avifauna from landuse changes (concomitantly with suggestions for remedial action) and more. Understanding the role of birds in ecosystem processes, long term studies on the biology and breeding of individual species, and inferring the evolutionary history of the endemic species and of those species that occur in small isolated populations in Angola are all areas for future research. The future of ornithological research and conservation in Angola is dependent on it being carried out by Angolans - outreach,
\end{abstract}

\footnotetext{
W. R. J. Dean $(\bowtie)$

DST-NRF Centre of Excellence at the FitzPatrick Institute, University of Cape Town,

Rondebosch, South Africa

e-mail: lycium@telkomsa.net

M. Melo

DST-NRF Centre of Excellence at the FitzPatrick Institute, University of Cape Town, Rondebosch, South Africa

CIBIO-InBIO, Centro de Investigação em Biodiversidade e Recursos Genéticos, Laboratório Associado, Universidade do Porto, Vairão, Portugal

Instituto Superior de Ciências da Educação de Huíla, Lubango, Angola e-mail: melo.martim@gmail.com
}

M. S. L. Mills

Instituto Superior de Ciências da Educação de Huíla, Lubango, Angola

A. P. Leventis Ornithological Research Institute, University of Jos, Jos, Plateau State, Nigeria e-mail: birdsangola@gmail.com 
capacity building, and advanced training must all come together in order to find and train the motivated ornithologists that such a biodiversity-rich country deserves.

Keywords Afromontane forests · Angolan escarpment · Conservation · Endemic bird area $\cdot$ Ornithology $\cdot$ Rare birds

\section{Early Ornithological History}

The richness, endemism and rarity of the avifauna in Angola has attracted many ornithologists, with the early studies during the late 1800s and first few years of the 1900s being almost entirely simple collections of birds. A chronology of bird collections is given in Table 14.1. Publications and results of many of these collections have been well covered by several authors, including Traylor (1963), Pinto (1983) and Dean (2000). From the 1960s until the early 1970s extensive collections were made at a number of localities in Angola by the Instituto de Investigação Científica de Angola (IICA) (Fig. 14.1). Details of some of these collections, and records of special interest, were published in a series of papers by Pinto (see references) providing much needed data on the biogeography and habitats of birds. The bird specimen collection assembled by the IICA, and now held by the Instituto Superior de Ciências da Educação (ISCED) in Lubango was catalogued by Mills et al. (2010). This was revised by Fernanda Lages and colleagues in 2016, aided by the discovery of the field notebooks associated with the collections. This database, of what is probably the third largest bird collection in Africa, will be available soon through the Global Biodiversity Information Facility (GBIF) portal.

Although a war for independence in Angola had been going on since 1961, armed conflict escalated with the start of a civil war in 1975, immediately after Angola became independent from Portugal. The war went on to last almost three decades, pre-empting any significant field-based biological research. Many of the reports on the avifauna of Angola that were published during the 1960s, 1970s and 1980s were "desktop" studies of museum specimens, all using data that had been collected before 1974. Despite issues with security and hazards imposed by the localised patches of unexploded ordinances and the extensive use of landmines, some avian studies were done in this period. Two East German biologists, Dr. Rainer Günther and Dr. Alfred Feiler, based at the Museum für Naturkunde der HumboldtUniversität zu Berlin and the Staatliches Museum für Tierkunde, Dresden, respectively, were commissioned to survey biodiversity, including birds, in Angola (Günther and Feiler 1986a, b). The ICBP (International Council for Bird Preservation, now BirdLife International) attempted a project to gather data on the status of (inter alia) the threatened endemic bird species on the Angolan "Scarp". The subsequent report adds little to what was known about the avifauna of this area, but the report usefully outlines the major threats to the biodiversity in the southernmost patches of Guinea-Congolian forest (Hawkins 1993).

It was only after the war ended definitely in 2002 that ornithologists returned to the country with most expeditions targeting the regions that had been classified as Important Bird Areas (IBAs, Dean 2001) and, in particular, the core habitats of the 
Table 14.1 A chronology of the collecting expeditions made in Angola, adapted from Traylor (1963) and Dean (2000), and reproduced, in part, by courtesy of the British Ornithologists' Union

\begin{tabular}{|c|c|}
\hline $\begin{array}{l}1850- \\
1892\end{array}$ & $\begin{array}{l}\text { J. Anchieta collected birds mainly in central Angola. The specimens, many of which } \\
\text { were Types, were described and reported on by Bocage in a number of separate } \\
\text { papers, summarised up to } 1881 \text { (Bocage } 1877,1881 \text { ). }\end{array}$ \\
\hline $\begin{array}{l}1858- \\
1868\end{array}$ & $\begin{array}{l}\text { J. J. Monteiro lived in Angola and collected birds. His collections, together with } \\
\text { those made by Charles Hamilton (a visitor), were reported on by Hartlaub and } \\
\text { Monteiro (1860), Hartlaub (1865), Sharpe and Monteiro (1869) and Sharpe (1871). }\end{array}$ \\
\hline $\begin{array}{l}1876- \\
1877\end{array}$ & $\begin{array}{l}\text { A. Lucan and L. A. Petit collected birds in Cabinda. Some of their specimens were } \\
\text { deposited in the Natural History Museum, Tring. The collection was reported on by } \\
\text { Sharpe and Bouvier }(1876 a, b, 1877,1878) .\end{array}$ \\
\hline $\begin{array}{l}1880 \text { and } \\
1887\end{array}$ & $\begin{array}{l}\text { A. W. Eriksson collected in Cunene, between the Cunene and Cubango rivers. His } \\
\text { specimens are in the Älvsborgs Länsmuseum, Vänersborg, Sweden (for details see } \\
\text { Rudebeck } 1955 \text { and Lundevall and Ängermark 1989), and in the Zoological } \\
\text { Museum, Uppsala, Sweden. }\end{array}$ \\
\hline $\begin{array}{l}1884- \\
1888\end{array}$ & $\begin{array}{l}\text { P. J. van der Kellen collected for the Nationaal Natuurhistorisch Museum, Leiden, } \\
\text { in Namibe and Huíla (Büttikofer } 1888,1889 \mathrm{a}, \mathrm{b} \text { ). }\end{array}$ \\
\hline $\begin{array}{l}\text { Early } \\
1900 \mathrm{~s}\end{array}$ & $\begin{array}{l}\text { Francisco Newton, a Portuguese naturalist, collected in southern Cuanza-Norte and } \\
\text { along the coast (Seabra 1905-1907). Some of the material he collected is in the Museu } \\
\text { de História Natural - Zoologia, Oporto (Seabra 1905a, b, 1906a, b, c, d, 1907). }\end{array}$ \\
\hline 1901 & $\begin{array}{l}\text { C. H. Pemberton collected along the Cunene River and in the area between the } \\
\text { Cuanza River and Bailundo for the Rothschild's Museum at Tring, UK. }\end{array}$ \\
\hline $\begin{array}{l}1903- \\
1906\end{array}$ & $\begin{array}{l}\text { W. J. Ansorge collected extensively throughout western Angola for the Rothschild's } \\
\text { Museum at Tring, UK. }\end{array}$ \\
\hline $\begin{array}{l}1908- \\
1909\end{array}$ & W. J. Ansorge collected in Cuanza-Norte for the British Museum in London. \\
\hline $\begin{array}{l}1910- \\
1911\end{array}$ & $\begin{array}{l}\text { W. Lowe spent a few days collecting in December } 1910 \text { and March } 1911 \text { in the } \\
\text { Luanda area (Bannerman 1912). }\end{array}$ \\
\hline $\begin{array}{l}1912- \\
1913\end{array}$ & $\begin{array}{l}\text { Some birds were collected in Cuando Cubango, Cunene and Huíla by the Mission } \\
\text { Rohan-Chabot (Ménégaux and Berlioz 1923). }\end{array}$ \\
\hline $\begin{array}{l}1920 \text { s and } \\
1930 \text { s }\end{array}$ & $\begin{array}{l}\text { R. Braun lived and studied birds mainly in Cuanza-Norte, northern Malanje and on } \\
\text { the escarpment of Cuanza-Sul (Braun 1930, 1934; Sick 1934; Stresemann 1934, } \\
\text { 1937). }\end{array}$ \\
\hline 1925 & $\begin{array}{l}\text { R. Boulton collected in Namibe, Huíla and Benguela for the American Museum of } \\
\text { Natural History. }\end{array}$ \\
\hline $\begin{array}{l}1926- \\
1927\end{array}$ & $\begin{array}{l}\text { H. Lynes and B. B. Osmaston collected cisticolas on the Huambo highlands and } \\
\text { along the Benguela coast. }\end{array}$ \\
\hline 1927 & $\begin{array}{l}\text { H. \& C. Chapman collected on the central plateau for the American Museum of } \\
\text { Natural History. }\end{array}$ \\
\hline 1928 & $\begin{array}{l}\text { P. Koester collected in the highlands of Huambo and southern Cuanza-Sul and sent } \\
\text { the skins to O. Neumann. Some of these skins are now in the Museum of } \\
\text { Comparative Zoology, Harvard University. }\end{array}$ \\
\hline $\begin{array}{l}1928- \\
1929 \\
1932- \\
1933\end{array}$ & $\begin{array}{l}\text { A. Monard }(1932,1934) \text { collected in eastern and southern Huíla and in Lunda- } \\
\text { Norte. His specimens are in the Musée D'Histoire Naturelle, La-Chaux-de-Fonds, } \\
\text { Switzerland. }\end{array}$ \\
\hline $\begin{array}{l}1929- \\
1930\end{array}$ & $\begin{array}{l}\text { The gray African expedition of the Academy of Natural Sciences, Philadelphia } \\
\text { made two collections in Bié and southern Malanje (Bowen 1931, 1932). }\end{array}$ \\
\hline
\end{tabular}


Table 14.1 (continued)

\begin{tabular}{|c|c|}
\hline 1930 & $\begin{array}{l}\text { L. Fenaroli collected in the northwest and on the north-central plateau (Moltoni } \\
\text { 1932). }\end{array}$ \\
\hline $\begin{array}{l}1930- \\
1931\end{array}$ & $\begin{array}{l}\text { H. Lynes and J. Vincent collected cisticolas and other species on the plateau and } \\
\text { from Dundo, Lunda-Norte, to Vila Luso (now Luena) in Moxico (Lynes and Sclater } \\
\text { 1933, 1934). }\end{array}$ \\
\hline 1931 & $\begin{array}{l}\text { R. Boulton collected in central and southern Angola for the Carnegie Museum of } \\
\text { Natural History (Boulton 1931). }\end{array}$ \\
\hline $\begin{array}{l}1931- \\
1934\end{array}$ & $\begin{array}{l}\text { Jean Bodaly made large collections in northern Bié and sent them to the Carnegie } \\
\text { Museum and Chicago Natural History Museum (now Field Museum of Natural } \\
\text { History). }\end{array}$ \\
\hline $\begin{array}{l}1931- \\
1934\end{array}$ & $\begin{array}{l}\text { H. K. Prior collected at Dondi in Huambo and sent skins to the Field Museum of } \\
\text { Natural History. }\end{array}$ \\
\hline $\begin{array}{l}1932- \\
1933\end{array}$ & $\begin{array}{l}\text { The Phipps-Bradley Expedition made a collection on the plateau for the American } \\
\text { Museum of Natural History. }\end{array}$ \\
\hline $\begin{array}{l}1933- \\
1934\end{array}$ & $\begin{array}{l}\text { H. Lynes and J. Vincent collected birds (mainly cisticolas) in Benguela, Huambo, } \\
\text { southern Lunda-Sul and northern Lunda-Norte (Lynes 1938). }\end{array}$ \\
\hline $\begin{array}{l}1944- \\
1949\end{array}$ & C. M. N. White (1950) collected in areas in the extreme east of Moxico. \\
\hline 1952 & $\begin{array}{l}\text { H. A. Beatty collected in the northwest and sent skins to the Field Museum of } \\
\text { Natural History, Chicago. }\end{array}$ \\
\hline 1954 & $\begin{array}{l}\text { W. Serle visited coastal areas for only } 1 \text { week but published interesting data (Serle } \\
\text { 1955). }\end{array}$ \\
\hline $\begin{array}{l}1954- \\
1955\end{array}$ & $\begin{array}{l}\text { G. Heinrich (1958a, b, c) collected extensively in the western half of Angola and } \\
\text { sent some skins to the Field Museum of Natural History, Chicago, and the } \\
\text { Zoologisches Institut und Zoologisches Museum, Hamburg (Meise 1958). }\end{array}$ \\
\hline 1956 & $\begin{array}{l}\text { G. Rudebeck collected for the Visser-Transvaal Museum Expedition in } \\
\text { southwestern Angola, but only a few details have been published (Rudebeck 1958). }\end{array}$ \\
\hline 1957 & $\begin{array}{l}\text { B. P. Hall led an expedition to central and western Angola which resulted in two } \\
\text { major publications on zoogeography and taxonomy (Hall 1960a, b). }\end{array}$ \\
\hline 1957 & $\begin{array}{l}\text { R. Boulton collected in northwestern and northeastern Angola, and sent skins to the } \\
\text { Field Museum of Natural History, Chicago. }\end{array}$ \\
\hline $\begin{array}{l}1957- \\
1958\end{array}$ & $\begin{array}{l}\text { G. Heinrich collected in Cuanza-Norte, Malanje and Lunda-Norte for the Peabody } \\
\text { Museum of Natural History, Yale University, and the Smithsonian Institution. }\end{array}$ \\
\hline $\begin{array}{l}1958- \\
1973\end{array}$ & $\begin{array}{l}\text { Staff at the Instituto de Investigação Científica de Angola (IICA) collected in } \\
\text { Moxico, Bengo, Luanda, Malange, Cuanza-Sul, Bié, Benguela, Huíla, Namibe and } \\
\text { Cuando-Cubango for the IICA collection at Lubango. }\end{array}$ \\
\hline 1972 & $\begin{array}{l}\text { W.R.J. Dean collected in Huíla, Malange and Cabinda for the Peabody Museum, } \\
\text { New Haven (Dean 1974). }\end{array}$ \\
\hline 1972 & $\begin{array}{l}\text { M.E. Ferreira collected in Huíla for the Zoologishes Forschungsinstitut und } \\
\text { Museum Alexander Koenig, Bonn. }\end{array}$ \\
\hline 1973 & $\begin{array}{l}\text { W.R.J. Dean collected in Huíla, Cuanza-Norte, Cuanza-Sul and Malange for the } \\
\text { Peabody Museum, New Haven (Dean 1974). }\end{array}$ \\
\hline $\begin{array}{l}1982- \\
1983\end{array}$ & $\begin{array}{l}\text { R. Günther and A. Feiler collected in Luanda, Bengo, Uige, Cuanza-Norte and } \\
\text { Lunda-Norte for the Staatliches Museum für Tierkunde, Dresden and the Museum } \\
\text { für Naturkunde der Humboldt-Universität zu Berlin (Günther and Feiler 1986a, b) }\end{array}$ \\
\hline
\end{tabular}




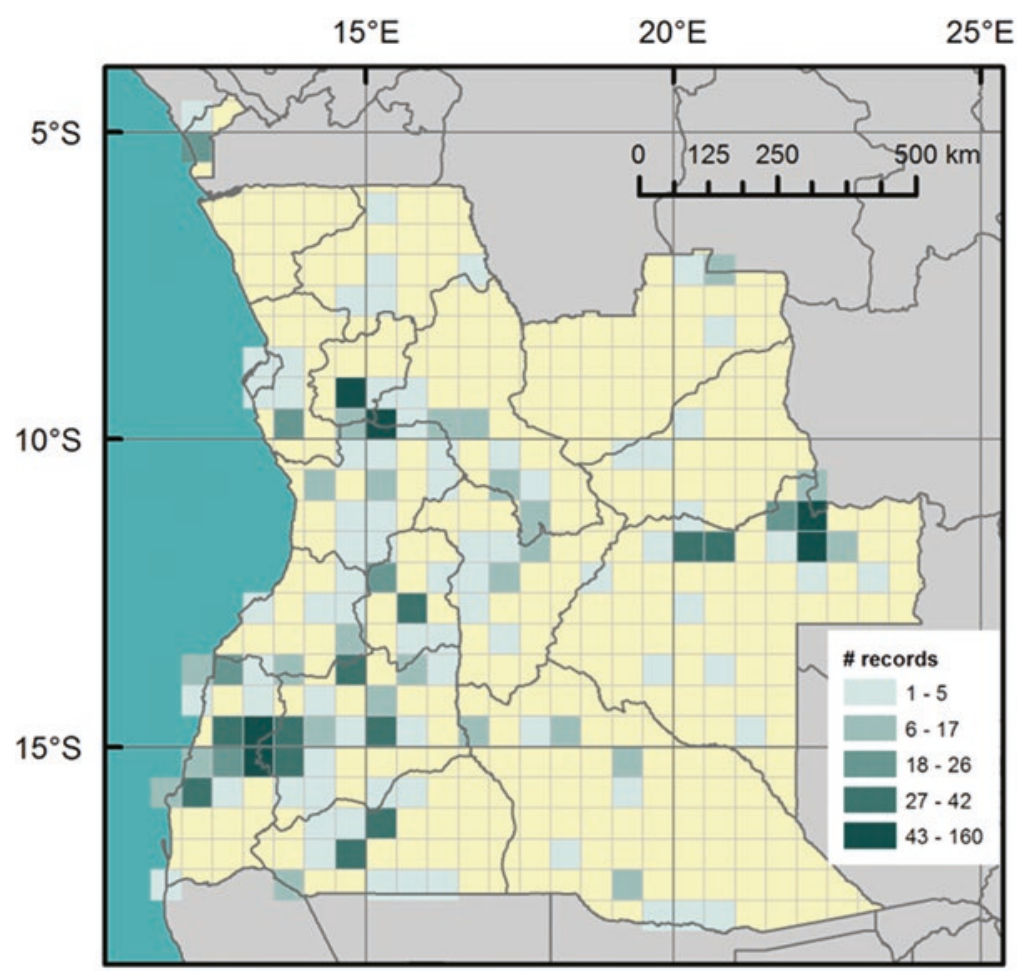

Fig. 14.1 Localities where bird specimens were collected by the Instituto de Investigação Científica de Angola (IICA) with duplicates held by the Instituto de Investigação Científica Tropical (IICT), shown as the number of specimens collected in each 30-minute square. (Figure extracted from Monteiro et al. (2014) and reproduced by permission of the authors)

endemic birds: the forests of the Western Escarpment and the highlands. Over the last 15 years the knowledge of avian diversity, distribution and biogeography for the country has steadily increased, with several species new to the Angola list being recorded from areas that had never been previously explored.

\section{Recent History and the Exponential Increase in Information on Birds}

One of the first "post war" studies was the publication of field notes on the Greystriped Francolin Francolinus griseostriatus that provided some information on the biology of this endemic and rare species (Vaz Pinto 2002). Studies of individual species and surveys of areas of particular interest gained momentum during the early 2000s, with notes on the Gabela Akalat Sheppardia gabela (Mills et al. 2004), and more general reports on the conservation status and vocalisations of endemic and threatened bird species from the forests of the western escarpment ('Scarp forests') of Angola (Ryan et al. 2004; Mills 2010) and a survey of the birds in Cumbira 
Forest, Gabela (Sekercioğlu and Riley 2005). Cumbira Forest, a representative of Central Scarp forests, is rich in endemic bird species, and has since been the focus of one of the most detailed studies of birds in Angola (Cáceres et al. 2015, 2016, 2017). Most recent publications on birds in Angola, however, deal with extensions of distributional range, vocalisations and lists of birds from specific areas, all providing data towards an atlas of Angolan birds (Table 14.2). Reports on the birds of particular areas, such as Cangandala National Park (Mills et al. 2008) and the Soyo area (Dean and le Maitre 2008; Stavrou and Mills 2013) are valuable in that there is a large gap in time between when the places were last surveyed for birds and now. The avifauna of many areas is known only from collections of specimens during the 1950s and there have been significant and rapid changes in landuse in many areas after the war, such as with the conversion of old-growth miombo woodland for charcoal making, or the replacement of secondary forest and shade-forest coffee plantations by slash-and-burn agriculture in the Scarp (Leite et al. 2018), the most important area of bird endemism (Cáceres et al. 2017). Reports on the avifauna of Mount Moco (Mills et al. 2011a, b), the Namba Mountains (Mills et al. 2013a, b), and Lagoa Carumbo (Mills and Dean 2013) have highlighted the bird species richness of these areas and, inter alia, noted threats to the local ecosystems and their

Table 14.2 New species on the Angolan bird list recorded since 1975

\begin{tabular}{l|l|l}
\hline Common name & Species & References \\
\hline Northern Royal Albatross & Diomedea (epomorpha) sanfordi & Lambert (2001) \\
\hline Spectacled Petrel & Procellaria conspicillata & Lambert (2001) \\
\hline Red-billed Tropicbird & Phaethon aethereus & Lambert (2001) \\
\hline White-tailed Tropicbird & Phaethon lepturus & Lambert (2001) \\
\hline Cape Vulture & Gyps coprotheres & Bamford et al. (2007) \\
\hline Lesser Spotted Eagle & Aquila pomarina & Meyburg et al. (2001) \\
\hline Booted Eagle & Hieraaetus pennatus & Sinclair (1981) \\
\hline Red-necked Falcon & Falco chicquera & Mills et al. (2016) \\
\hline Pacific Golden Plover & Pluvialis fulva & Mills (2015) \\
\hline Red Phalarope & Phalaropus fulicarius & Lambert (2001) \\
\hline European Oystercatcher & Haematopus ostralegus & Simmons et al. 2009 \\
\hline Black-headed Gull & Chroicocephalus ridibundus & Lambert (2001) \\
\hline Little Tern & Sternula albifrons & Lambert (2001) \\
\hline Greater Crested Tern & Thalasseus bergii & Dean et al. (2002) \\
\hline Lemon Dove & Columba larvata & Mills and Dowd (2007) \\
\hline Yellow-throated Cuckoo & Chrysococcyx flavigularis & Mills et al. (2013a, b) \\
\hline Pink-billed Lark & Spizocorys conirostris & Mills (2006) \\
\hline Red-tailed Leaflove & Phyllastrephus scandens & Mills et al. (2013a, b) \\
\hline Forest Swallow & Petrochelidon fuliginosa & Mills and Tebb (2015) \\
\hline South African Cliff Swallow & Petrochelidon spilodera & Mills et al. (2013a, b) \\
\hline Singing Cisticola & Cisticola cantans & Dean et al. (2003) \\
\hline White-collared Oliveback & Nesocharis ansorgei & Mills and Vaz Pinto (2015) \\
\hline
\end{tabular}

The list does not include unconfirmed records

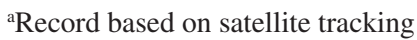


importance for conservation. Notes on rare and little known species, such as Brazza's Martin Phedina brazzae (Mills and Cohen 2007), Black-tailed Cisticola Cisticola melanurus (Mills et al. 2011a, b), Bocage's Sunbird Nectarinia bocagii (Mills 2013), and the Red-necked Falcon Falco chicquera (Mills et al. 2016), have provided some insights into the biology of these species. Breeding data for all species in Angola are few, but MSLM and co-workers (see references) have recently published several notes on the biology and first descriptions of nests and eggs and some useful notes on brood parasitism and nests of a number of species.

The creation of the Internet group Angola Birders by MSLM in 2012 has greatly facilitated and promoted the acquisition and sharing of data on bird distributions. This has led to a large number of records of the occurrence of species, some of which have cleared up distributional anomalies. For example, records of Black Bishop Euplectes gierowii by Pedro Vaz Pinto (2 June 2015), together with earlier records by MSLM, provide some evidence that the species is not as rare as previously thought (see Dean 2000). The Angola Birders Group has proved very useful, not only for new distribution records, but also for new breeding records. More importantly, it has generated interest in birds in many people, including diplomats and executives of companies now trading in Angola, who now spend their spare time "off the beaten track". Their contributions towards a national database (at present held by MSLM) of bird records are valuable. The facebook group "Angola Ambiente" has completely overtaken Angola Birders and is currently providing a lot of useful information.

One of the useful products from the national database of bird records is the bilingual annotated checklist published by Mills and Melo (2013), based on the catalogue of the specimen collection at Lubango (Mills et al. 2010) and sight records. This updates earlier lists, and includes some notes on unconfirmed and doubtful records of species unlikely to occur in Angola. These records vary from (probably) confusion with known species or sightings of species well outside their distribution range.

\section{The Richness of the Angolan Avifauna}

About 940 species of birds have been recorded in Angola (Mills and Melo 2013). This increases the number of species recorded for the country; a total of 915 species were listed by Dean (2000), and 12 additional species were added by Mills and Dean (2007), of which seven marine species, mostly pelagic, were recorded by Lambert (2001). Some specimens thought to be of Red-faced Cisticola proved to be those of an isolated population of Singing Cisticola Cisticola cantans (Dean et al. 2003), and the occurrence of the Lesser Spotted Eagle Aquila pomarina (Meyburg et al. 2001) and the Swift Tern Sterna bergii (Dean et al. 2002) have been verified. One additional species, Slaty Egret Egretta vinaceigula, has been added as a result of cataloguing the bird collection at Lubango (Mills et al. 2010). Observations made in poorly known areas of Angola by MSLM and co-workers have added additional 
species to the list, including the Yellow-throated Cuckoo Chrysococcyx flavigularis, [Red-tailed] Leaf-love Phyllastrephus scandens and South African Cliff Swallow Petrochelidon spilodera (Mills et al. 2013a, b). Developments in assessing species boundaries using molecular methods, have added another 16 species (Mills and Dean 2007). One example of this is the Common Fiscal Lanius collaris that has now been split into two species, the Northern Fiscal $L$. humeralis and Southern Fiscal $L$. collaris (Fuchs et al. 2011). There have also been some corrections to the list, such as specimens of the White-bellied Sunbird Cinnyrus talatala from Mount Moco and Mount Soque listed by Dean (2000) that were found to be miscatalogued Oustalet's Sunbirds Cinnyrus oustaleti (Mills and Dean 2007). There are also a number of avian taxa that require further investigation, either in the field or using molecular analyses to establish species boundaries (Mills and Dean 2007).

The list for Angola does not include 88 species for which there are sight records and that, in many cases, and for various reasons, are unlikely to occur in Angola (Mills and Melo 2013). Some species are simply misidentifications of similar, related species. Others, however, particularly migrant waders (shorebirds) from the Northern Hemisphere, may have been correctly identified, but require more records, photographs or specimens for verification. Unconfirmed species are dealt with by Mills and Dean (2007) and more fully by Mills and Melo (2013) and will not be listed here.

\section{Endemism in the Angolan Avifauna}

There are about 29 species of birds endemic to Angola, the number depending on the taxonomic authority that is followed (Table 14.3). Most occur in the forests of the Western Escarpment and in the last remnants of Afromontane forest of the highlands, the two core habitats of the Western Angola Endemic Bird Area (BirdLife International 2017). Two species, Red-backed Mousebird Colius castanotus and Bubbling Cisticola Cisticola bulliens, are widely distributed in Angola, including the Western Escarpment and associated coastal plains and in a range of woodlands and forest patches modified for the cultivation of coffee (Dean 2000).

The semi-evergreen humid forests of the Angolan Escarpment ('the Scarp Forests') are impoverished outliers of the Congolian rainforest (Huntley and Matos 1994). They have been the major speciation hotspot for birds in Angola by: (i) creating a barrier between arid-adapted species of the coastal plains and of the miombo woodlands of the plateau, (ii) creating a steep ecological gradient, and (iii) functioning as a refuge for moist forest specialists that were isolated here during the dry periods of the glacial cycles (Hall 1960a) - 75\% of the endemic bird species are associated with this region.

The Afromontane forests of west-central Angola make the most isolated representatives of all the Afromontane centres of endemism, separated by $>2000 \mathrm{~km}$ from other similar habitats. This isolation has allowed the development of plant and animal communities that are quite distinct from those of other montane centres. The 
Table 14.3 Provisional list of bird species endemic or near endemic to Angola, with their IUCN Red List Category, and main area of occurrence

\begin{tabular}{|c|c|c|c|c|c|c|}
\hline Scientific name & English name & I & $\mathrm{S}$ & M & $\mathrm{O}$ & $\mathrm{N}$ \\
\hline Pternistis griseostriatus & Grey-striped Francolin & VU & - & & & \\
\hline Pternistis swierstrai & Swierstra's Francolin & LC & & $\bullet$ & & \\
\hline Tauraco erythrolophus & Red-crested Turaco & LC & & & & \\
\hline Colius castanotus & Red-backed Mousebird & LC & • & & & \\
\hline Gymnobucco vernayi & Angola Naked-faced Barbet & $\mathrm{LC}$ & - & & & $*$ \\
\hline Lybius leucogaster & Angola White-headed Barbet & $\mathrm{LC}$ & - & & & $*$ \\
\hline Platysteira albifrons & White-fronted Wattle-eye & $\mathrm{LC}$ & - & & & \\
\hline Prionops gabela & Gabela Helmetshrike & $\mathrm{EN}$ & • & & & \\
\hline Malaconotus monteiri & Monteiro's Bushshrike & LC & - & & & 1 \\
\hline Laniarius amboimensis & Gabela Bushshrike & EN & $\bullet$ & & & \\
\hline Laniarius brauni & Braun's Bushshrike & EN & $\bullet$ & & & \\
\hline Phyllastrephus viridiceps & Angola White-throated Greenbul & $\mathrm{LC}$ & - & & & $*$ \\
\hline Phyllastrephus fulviventris & Pale-olive Greenbul & $\mathrm{LC}$ & • & & & \\
\hline Macrosphenus pulitzeri & Pulitzer's Longbill & $\mathrm{LC}$ & $\bullet$ & & & \\
\hline Cisticola bulliens & Bubbling Cisticola & LC & & & - & \\
\hline Cisticola bailunduensis & Huambo Cisticola & $\mathrm{LC}$ & & $\bullet$ & & $*$ \\
\hline Cisticola melanura & Black-tailed Cisticola & $\mathrm{LC}$ & & & $\bullet$ & \\
\hline Sheppardia gabela & Gabela Akalat & $\mathrm{LC}$ & $\bullet$ & & & \\
\hline Xenocopsychus ansorgei & Angola Cave-Chat & LC & $\bullet$ & $\bullet$ & & 2 \\
\hline Dioptrornis brunneus & Angola Slaty Flycatcher & $\mathrm{LC}$ & $\bullet$ & & & \\
\hline Nectarinia bocagii & Bocage's Sunbird & $\mathrm{LC}$ & & & • & \\
\hline Cinnyris ludovicensis & Ludwig's Double-collared Sunbird & $\mathrm{LC}$ & $\bullet$ & - & & 3 \\
\hline Ploceus temporalis & Bocage's Weaver & $\mathrm{LC}$ & & & $\bullet$ & \\
\hline Euplectes aureus & Golden-backed Bishop & $\mathrm{LC}$ & & & $\bullet$ & 4 \\
\hline Lagonosticta ansorgei & Ansorge's Firefinch & $\mathrm{LC}$ & & & $\bullet$ & \\
\hline Coccopygia bocagei & Angolan Swee Waxbill & $\mathrm{LC}$ & & & $\bullet$ & \\
\hline Estrilda thomensis & Cinderella Waxbill & $\mathrm{LC}$ & & & $\bullet$ & \\
\hline Macronyx grimwoodi & Grimwood's Longclaw & $\mathrm{LC}$ & & & $\bullet$ & \\
\hline Crithagra benguelensis & Benguela Seedeater & LC & & & $\bullet$ & \\
\hline
\end{tabular}

IUCN categories, $L C$ Least Concern, $N T$ Near Threatened, $V U$ Vulnerable, EN Endangered, $S$ Forests of the Western Escarpment ('Scarp forests'), $M$ Afromontane forests, $O$ Other habitats, $N$ Notes

1. Recent records from Cameroon are considered doubtful (Mills 2010)

2. Near-endemic as a marginal population was recently found in Namibia (Swanepoel 2013)

3. Isolated populations in Malawi and Tanzania sometimes treated as sub-species are better treated as distinct species (Bowie et al. 2016)

4. Population on São Tomé Island was very likely introduced by humans as cage birds (Jones and Tye 2006)

*indicates recent species splits proposed by HBW and BirdLife International (2017) following the criteria in Tobias et al. (2010). In these cases only phenotypic data (morphology and song) was used and it would be useful to measure the levels of genetic differentiation from sister taxa 
total number of endemic bird species associated with these forests is small (Table 14.3), but many endemic subspecies are present (Mills et al. 2011a, b) and molecular studies are likely to support the treatment of several of these populations as distinct species. It is likely that because of their small size, the Afromontane forests of Angola were not included in the 'Afromontane archipelago' biome as defined by White (1978; cf. Fig. 1). Current research has uncovered a key role of these forests in the evolutionary history of the bird communities of the montane forests of Africa. Genetic data, together with the reconstruction of past climates and associated habitats, have shown that the small Angolan Afromontane forests were areas of high climatic stability throughout glacial cycles and constituted the link between the montane bird communities of East Africa and the Cameroon mountains (Vaz da Silva 2015). For species such as the African Hill Babbler Sylvia [Pseudalcippe] abyssinica and Bocage's Akalat Sheppardia bocagei, populations were isolated in the Angola mountains from very early on and are likely to constitute distinct species (Vaz da Silva 2015).

Apart from the Afromontane and Scarp forests, most other vegetation types and bird habitats are all part of much larger areas that extend into Angola from (i) the North: Guinea-Congolian forests; (ii) the East: miombo woodlands; and (iii) the South: Namib Desert. The avifauna of these biomes is endemic to the habitat type and thus not confined to Angola. An exception might be Bocage's Sunbird Nectarinia bocagii that is known only from Angola (Dean 2000; Mills 2013) and western DRC (Dowsett et al. 2008), Black-tailed Cisticola Cisticola melanurus (Irwin 1991; Mills et al. 2011a, b) and the White-headed Robin-Chat Cossypha heinrichi that show a similar distribution. There are no data on the relative abundance of these species in the DRC, but in Angola they are considered uncommon to locally common (Dean 2000; Mills and Melo 2013), and thus Angola is very likely to house most of the population, giving them near endemic status. On the other hand, the formerly endemic Angolan Cave Chat Xenocopsychus ansorgei is now treated as 'nearendemic' after the discovery of an isolated population in northern Namibia (Swanepoel 2013).

\section{Commonness and Rarity}

The relative abundance of birds in Angola is covered by Mills and Melo (2013). Most bird species that are widespread in Angola are, if not common, then frequently seen. About 170 species can be considered uncommon (134 species) or rare (35 species). The status of many of the uncommon and rare species is uncertain - some species are known from a few, or a single specimen, collected a long time ago and not subsequently recorded. Examples are the Congo Serpent Eagle Dryotriorchis spectabilis, collected in 1954 at Canzele, Cuanza-Norte, and another specimen collected at Mwaoka, Lunda-Norte, in 1964, and not seen since. The status of the Lemon-bellied Crombec Sylvietta denti of which a single specimen was collected at Dundo, Lunda-Norte, in 1958, and a second specimen sound-recorded at Lago 
Carumbo (Mills and Dean 2013) is uncertain. Similarly, the status of the Longtailed Hawk Urotriorchis macrourus is not known. A specimen was collected at Cacongo (Lậndana) in Cabinda by L. Petit, probably in 1876, and not recorded since, despite an extensive collecting trip to Cabinda by the IICA in 1969 (Pinto 1972). Species that have restricted ranges with small populations in Angola, are generally not rare, and may be locally common within their particular habitat.

\section{Anomalies in Bird Distribution Ranges and Recent Findings}

A few species are known from isolated communities within certain areas, with the nearest conspecifics many kilometres away. These patterns could be real, or they could be the result of the geographical bias in surveys and collecting. Most collectors favoured the western half of Angola. With the exception of Lunda-Norte, and parts of Moxico, the coverage by collectors across the east-west gradient was poor (e.g., Fig. 3 in Monteiro et al. 2014). For a few species we can be certain that the gap in the distribution between western Angola and western Zambia is real, and is likely to be the result of relict mountain chains that no longer exist.

The recent exploration of places such as Lagoa Carumbo in Lunda-Norte has provided much new information on distributions thought to be disjunct (Mills and Dean 2013). Only 67 species had been collected in the Lagoa Carumbo area during the 1950s by Heinrich (1958a, b, c). Field surveys by MSLM in 2011 recorded 175 species, with 21 species that had been collected by Heinrich not seen. The data on the species seen at Lagoa Carumbo included new records for the area, extensions of ranges and two new records for Angola.

Some remarkable recent finds have been made. The presence of the Whitecollared Oliveback Nesocharis ansorgei in Angola was unknown and not even suggested until populations were found in 2011,2012, and 2013 at Quibaxi and Quitexe, Cuanza-Norte, and at Uíge (Mills and Vaz Pinto 2015). Before this the nearest known populations were $>1500 \mathrm{~km}$ away in eastern DRC.

\section{Ecotourism in Angola: Birding}

Ecotourism is becoming a significant means of raising funds for the protection of sites of high biodiversity value. With recent changes in the entry requirements for visitors, improvements in road and hotel infrastructure, and its high biodiversity, Angola stands to attract a large number of visitors for ecotourism purposes. Most of the key bird watching sites are unprotected, thus making income from tourism even more important (Cáceres 2011). For visiting birders the endemic and near-endemic birds (Table 14.3) are a major drawcard, but the country also holds a variety of specials summarised in Mills (2018), including Finsch's Francolin Scleroptila finschii, Anchieta's Barbet Stactolaema anchietae, Angola Batis Batis minulla, 
Yellow-throated Nicator Nicator vireo, Angola Lark Mirafra angolensis, Brazza's Martin Phedina brazzae, Black-and-rufous Swallow Hirundo nigrorufa, Sharptailed Starling Lamprotornis acuticaudus, White-headed Robin-Chat Cossypha heinrichi, Forest Scrub Robin Erythropygia leucosticta, Oustalet's Sunbird Cinnyris oustaleti, Black-chinned Weaver Ploceus nigrimentus, Dusky Twinspot Euschistospiza cinereovinacea and Black-faced Canary Crithagra capistrata, all arguably seen more easily in Angola than any other country. Table 14.4 lists the key sites for visiting birders, with main habitats and most sought-after birds - some of which are depicted on Fig. 14.2. Most 'Namibian specials' are also easily found in Angola.

\section{Where to from Here? Future Directions for Ornithological Research in Angola}

As noted in the introduction, it is clear that there have been major advances in the knowledge of avian species diversity and distribution and in the relative abundance of species during the last 15 years. This information is crucial to identify potential conservation areas, although more local surveys of bird communities are needed to paint a complete picture. We can run algorithms on the species distribution and abundance data to identify precisely where conservation areas should be, and the inclusion of other parameters such as endemism and/or threat levels can be used to

Table 14.4 Key sites for birdwatching in Angola

\begin{tabular}{|c|c|c|}
\hline Site name & Habitat & Key birds \\
\hline $\begin{array}{l}\text { Northern } \\
\text { Escarpment }\end{array}$ & Congo forest & Braun's Bushshrike, Congo basin birds \\
\hline $\begin{array}{l}\text { Calandula } \\
\text { Falls area }\end{array}$ & $\begin{array}{l}\text { Gallery forest, } \\
\text { miombo }\end{array}$ & $\begin{array}{l}\text { White-headed Robin-Chat, Anchieta's Barbet, Bannerman's } \\
\text { Sunbird }\end{array}$ \\
\hline Quiçama NP & $\begin{array}{l}\text { Gallery forest, } \\
\text { thickets }\end{array}$ & $\begin{array}{l}\text { Grey-striped Francolin, White-fronted Wattle-eye, } \\
\text { Monteiro's Bushshrike, Gabela Helmetshrike, Bubbling } \\
\text { Cisticola, Red-backed Mousebird }\end{array}$ \\
\hline $\begin{array}{l}\text { Cumbira } \\
\text { Forest }\end{array}$ & Forest & $\begin{array}{l}\text { Gabela Akalat, Gabela Bushshrike, Pulitzer's Longbill, } \\
\text { Red-crested Turaco, Hartert's Camaroptera, Black-faced } \\
\text { Canary, Forest Scrub Robin }\end{array}$ \\
\hline Mount Moco & $\begin{array}{l}\text { Montane forest, } \\
\text { grassland, } \\
\text { miombo }\end{array}$ & $\begin{array}{l}\text { Swierstra's Francolin, Finsch's Francolin, Ludwig's } \\
\text { Double-collared Sunbird, Bocage's Sunbird, Black-and- } \\
\text { rufous Swallow, Dusky Twinspot, Angola Lark }\end{array}$ \\
\hline Benguela area & Arid bushveld & $\begin{array}{l}\text { Hartlaub's Francolin, White-tailed Shrike, Bare-cheeked } \\
\text { Babbler }\end{array}$ \\
\hline Tundavala & $\begin{array}{l}\text { Montane forest, } \\
\text { grassland, rocks }\end{array}$ & $\begin{array}{l}\text { Angola Cave Chat, Swierstra's Francolin, Angola Swee } \\
\text { Waxbill, Angola Slaty Flycatcher, Oustalet's Sunbird, } \\
\text { Ludwig's Double-collared Sunbird }\end{array}$ \\
\hline $\begin{array}{l}\text { Lubango- } \\
\text { Namibe }\end{array}$ & $\begin{array}{l}\text { Arid bushveld, } \\
\text { desert }\end{array}$ & $\begin{array}{l}\text { Cinderella Waxbill, Benguela Long-billed Lark, Rüppell's } \\
\text { Korhaan }\end{array}$ \\
\hline
\end{tabular}




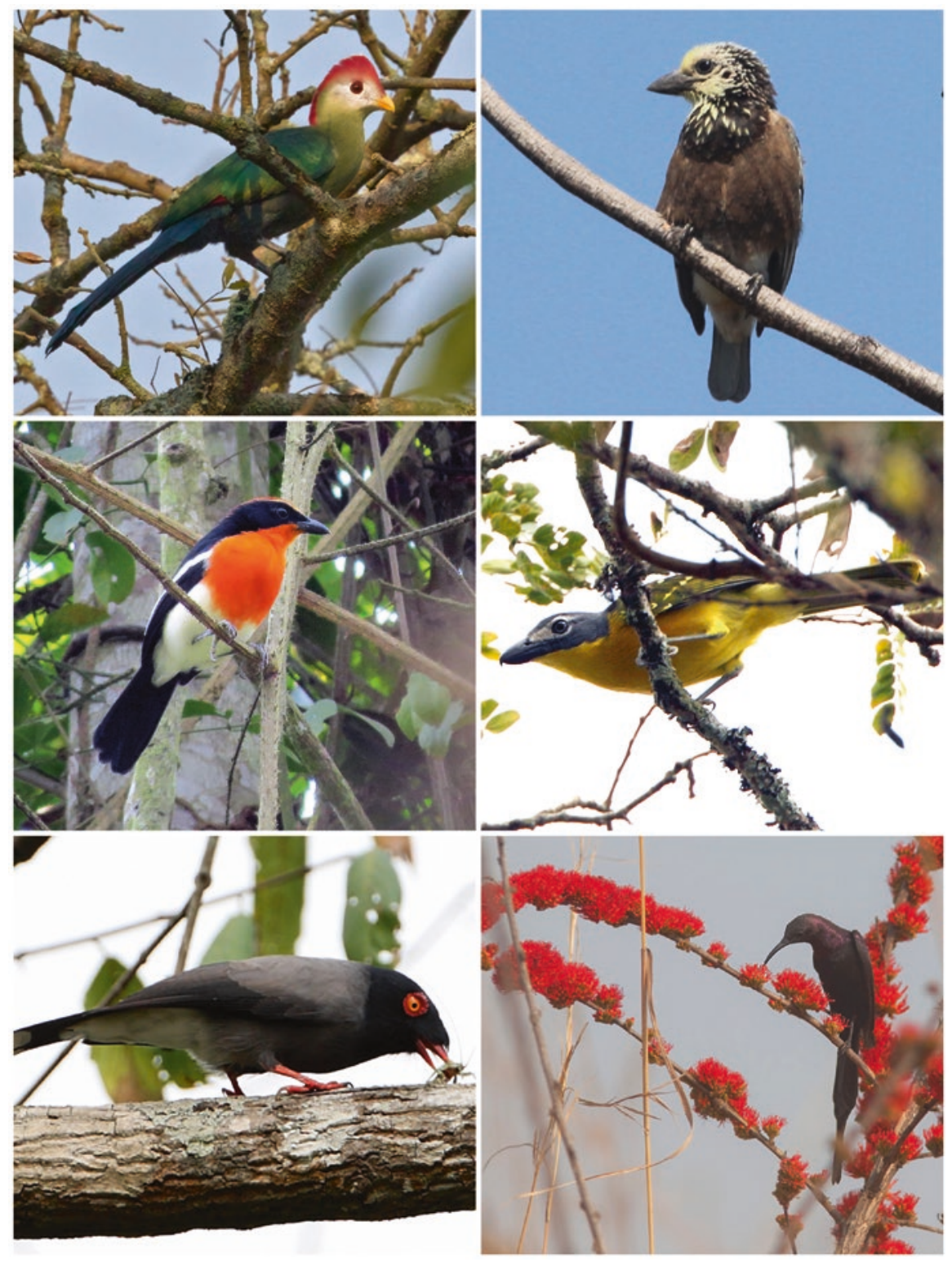

Fig. 14.2 Some special birds of Angola. Top to bottom, left to right: Red-crested Turaco, the endemic national bird of Angola. (Photo: Lars Petersson); Anchieta's Barbet, a sought-after species with a range extending to the DRC and Zambia but best seen in Angola. (Photo: Maans Booysen); Braun's Bushshrike, an endemic restricted to the forests of the northern escarpment. (Photo: Fiona Tweedie); Monteiro's Bushshrike, a difficult-to-see endemic associated primarily with the central escarpment. (Photo: Tasso Leventis); Gabela Helmetshrike, an endemic that occurs primarily at the base of the central escarpment, as in Quiçama NP. (Photo: Tasso Leventis); Bocage's Sunbird is only present in the highlands of Angola and the southwest of the DRC. (Photo: Alexandre Vaz) 
prioritise conservation efforts. Detailed data on patterns of bird diversity and conservation threats have been obtained for the core habitats of the only Endemic Bird Area of Angola: the Afromontane forests at Mount Moco (Mills et al. 2011a, b) and at the Namba Mountains (Mills et al. 2013a, b); and the Angolan Scarp forests, in particular for the central scarp forests where most endemism is concentrated (Mills 2010), with special emphasis in Cumbira Forest (Cáceres et al. 2015, 2016, 2017).

So far, and understandably, almost all the research on the birds of Angola has been on species diversity and distribution patterns, and not processes. Avian diversity surveys - that would feed a permanently updated atlas for the breeding birds of Angola - should continue, as many areas remain poorly explored or not visited at all for decades. In parallel with such exploration efforts, research on ecological and evolutionary processes must be promoted, as this will provide the information that ultimately is essential for guiding conservation efforts.

Very few studies have been carried out on the biology of individual species, no long-term studies of breeding have been done, and the nests and eggs of many species have yet to be discovered (e.g., Mills and Vaz 2011). Seed dispersal and frugivory by birds in Angola is another field that needs investigation, particularly now where so much habitat is being destroyed for slash-and-burn cultivation and charcoal making. Birds can play a key role in the rehabilitation of damaged areas. Seeds regurgitated by birds often germinate below roost sites, and the seedlings can be collected and planted out. Rehabilitation initiatives are already underway, albeit at a small scale, on Mount Moco and Cumbira. The Mount Moco reforestation project has been running since 2010, with the community-run nursery holding over 1400 saplings grown from locally collected seeds, and with almost 950 trees planted back in the wild (MSLM, unpublished). The Cumbira project is still at its early steps, with the creation of a pilot-nursery (Aimy Cáceres \& Ninda Baptista, unpublished).

Research on the evolutionary history of the endemic species and subspecies of Angola is likely to provide novel insights into bird diversification in Africa and on the uniqueness of the Angolan avifauna (see Endemism section above). The use of molecular tools will clarify the taxonomic status of species with small and isolated populations in Angola such as the Orange Ground Thrush Geokichla gurneyi restricted to Mount Namba or Margaret's Batis Batis margaritae present only on Mount Moco and Namba, and separated from its nearest conspecific in western Zambia by about $800 \mathrm{~km}$. Moreover, the two subspecies occupy rather different habitats - in Angola Margaret's Batis is present in patches of Afromontane forest, whereas in Zambia the species is present in dissimilar evergreen Cryptosepalum forest. It is highly likely that the two forms constitute well-separated evolutionary lineages and could be considered different species. This situation, with one "subspecies" present in western Angola and the nearest other "subspecies" present 800$900 \mathrm{~km}$ to the east in Zambia or the Katanga area is repeated in many of the western Angolan avian taxa, and raises many questions about whether the isolated populations are two recently diverged forms of one species, or two species. Similarly, the identification of the complex of swamp-dwelling weavers along the eastern border of Angola, western Zambia and Katanga is still something of a mystery. The question 
has been addressed by several authors (Louette and Benson 1982; Louette 1984; Dean 1996) but remains unsettled. Molecular tools may be required to clarify the situation.

The distinctive endemic subspecies of Horus Swift (Apus horus fuscobrunneus) is known from a single series of specimens taken on the coastal plain of Namibe and has not been recorded in Angola since the early 1970s. Likewise, the endemic subspecies of White-headed Barbet (Lybius leucocephalus leucogaster), which was fairly common around the southern escarpment, was only rediscovered in 2017, in Tundavala, after almost 40 years of being undetected (Baptista and Mills 2018). Both taxa have been proposed as endemic species, so finding extant populations in the field is a high priority.

Future ornithological research will only succeed and grow with greater local input. There is a great need to stimulate more interest within Angola for the study of birds, both by engaging students more directly and producing relevant educational materials for local students. To these ends, joint Portuguese-English language books have already been produced on The Common Birds of Luanda (Mills and Melo 2015) and The Special Birds of Angola (Mills 2018), to raise interest and awareness. A basic handbook on ornithology relevant to Angola and written in Portuguese would be a welcome addition. There is also a need for field courses to provide training to Angolan students, working together with Angolan universities. Most importantly, finding ways to encourage the interest of local students in field studies is greatly needed.

\section{Appendix 14.1 Publications Post 1975 Not Cited in the Text}

Beel C (1992) Species new to the Angolan list. Zambian Ornithological Society Newsletter 22(1):2

Bowen PStJ (1979) Some notes on Margaret's Batis (Batis margaritae) in Zambia. Bulletin of the Zambian Ornithological Society 11:1-10

Bowen PStJ (1983) The Black-collared Bulbul Neolestes torquatus in Mwinilunga District and the first Zambian breeding record. Bulletin of the Zambian Ornithological Society 13-15:7-14

Bowen PStJ, Colebrook-Robjent JFR (1984) The nest and eggs of the Black-andrufous Swallow Hirundo nigrorufa. Bulletin of the British Ornithologists' Club 104:146-147

Braine S (1990) Records of birds of the Cunene River estuary. Lanioturdus 25:38-44

Brooke RK (1981a) The Feral Pigeon - a 'new' bird for the South African list. Bokmakierie 33:37-40

Brooke RK (1981b) The seabirds of the Moçâmedes Province, Angola. Gerfaut 71:209-225

Collar NJ (1998) Monotypy of Francolinus griseostriatus. Bulletin of the British Ornithologists' Club 118:124-126 
Dean WRJ (1976) Breeding records of Crex egregia, Myrmecocichla nigra and Cichladusa ruficauda from Angola. Bulletin of the British Ornithologists' Club 96:48-49

Dean WRJ (1988) The avifauna of Angolan miombo woodlands. Tauraco 1:99-104

Dean WRJ (2001) The distribution of vultures in Angola. Vulture News 45:20-25

Dean WRJ (2006) Age structure of a Palm-nut Vulture Gypohierax angolensis population. Vulture News 55:8-9

Dean WRJ (2007) Type specimens of birds (Aves) in the Transvaal Museum collection. Annals of the Transvaal Museum 44:67-121

Dean WRJ, Milton SJ (2005) Stomach contents of birds (Aves) in The Natural History Museum, Tring, U.K., collected in southern Africa, northern Mozambique and Angola. Durban Museum Novitates 30:15-23

Dean WRJ, Milton SJ (2007) Some additional breeding records for birds in Angola. Ostrich 78:645-648

Dean WRJ, Vernon CJ (1988) Notes on the White-winged Babbling Starling Neocichla gutturalis in Angola. Ostrich 59:39-40

Dean WRJ, Sandwith M, Milton SJ (2006) The bird collections of C. J. Andersson in southern Africa, 1850-1867. Archives of Natural History 33:159-171

Dean WRJ, Walters MP, Dowsett RJ (2003) Records of birds breeding collected by Dr WJ Ansorge in Angola and Gabon. Bulletin of the British Ornithologists' Club 123:239-250

Dean WRJ, Franke U, Joseph G, et al. (2012) Type specimens in the bird collection at Lubango, Angola. Bulletin of the British Ornithologists' Club 132:41-45

Dean WRJ, Franke U, Joseph G, et al. (2014) Further breeding records for birds (Aves) in Angola. Durban Museum Novitates 36:1-36

Dean WRJ, Huntley MA, Huntley BJ, et al. (1988) Notes on some birds of Angola. Durban Museum Novitates 14:43-92

Lambert K (2006) Seabirds sighted in the waters off Angola, 1966-1988. Marine Ornithology 34:77-80

Louette M (2002) Relationship of the Red-thighed Sparrowhawk Accipiter erythropus and the African Little Sparrowhawk A. minullus. Bulletin of the British Ornithologists' Club 122:218-222

Mendelsohn JM, Haraes L (2018) Aerial census of Cape Cormorants and Cape Fur Seals at Baía dos Tigres, Angola. Namibian Journal of Environment 2A:1-6

Meyburg B-U, Mendelsohn JM, Ellis DH, et al. (1995) Year-round movements of a Wahlberg's Eagle Aquila wahlbergi tracked by satellite. Ostrich 66:35-140

Mills MSL (2007a) Swierstra's Francolin Francolinus swierstrai: a bibliography and summary of specimens. Bulletin of the African Bird Club 14:175-180

Mills MSL (2007b) Vocalisations of Angolan Birds. Vol. 1. CD. Birds Angola \& Birding Africa, Cape Town

Mills MSL (2009) Vocalisations of Angolan birds: new descriptions and other notes. Bulletin of the African Bird Club 16:150-166

Mills MSL (2014a) Dusky Twinspot Euschistospiza cinereovinacea, a new host species for indigobirds Vidua. Bulletin of the African Bird Club 21:193-199 
Mills MSL (2014b) Observations of the rarely seen aerial display of Short-winged Cisticola Cisticola brachypterus. Bulletin of the African Bird Club 21:200-201

Mills MSL, Oschadleus HD (2013). Black-chinned Weaver Ploceus nigrimentus in Angola, and its nest. Bulletin of the African Bird Club 20:60-66

Mills MSL, Vaz Pinto P, Haber S (2012). Grey-striped Francolin Pternistis griseostriatus: specimens, distribution and morphometrics. Bulletin of the African Bird Club 19:172-177

Mills MSL, Melo M, Borrow N, et al (2011) The Endangered Braun's Bushshrike Laniarius brauni: a summary. Bulletin of the African Bird Club 18:175-181

Morant PD (Compiler). (1996) Environmental Study of the Kunene River Mouth. CSIR Report EMAS-C96023. CSIR, Stellenbosch

Oschadleus HD, Mills MSL, Monadjem A (2014) Roadside colony densities of weavers in southern Angola. Lanioturdus 47:17-20

Paterson J, Boorman M, Glendenning J, et al. (2009) Vagrants, range extensions and interesting bird records for Skeleton Coast Park Namibia and southern Angola. Lanioturdus 42:4-10

Ripley SD, Bond GM (1979) A third set of additions to the avifauna of Angola. Bulletin of the British Ornithologists' Club 99:140-142

Ryan PG, Cooper J, Stutterheim CJ (1984) Waders (Charadrii) and other coastal birds of the Skeleton Coast, South West Africa. Madoqua 14:71-78

Simmons RE (2010) First breeding records for Damara Terns and density of other shorebirds along Angola's Namib Desert coast. Ostrich 81:19--23

Simmons RE, Braby R, Braby SJ (1993) Ecological studies of the Cunene River mouth: avifauna, herpetofauna, water quality, flow rates, geomorphology and implications of the Epupa Dam. Madoqua 18:163-180

Simmons RE, Sakko A, Paterson J, et al. (2010) Birds and conservation significance of the Namib Desert's least known coastal wetlands: Baia and Ilha dos Tigres, Angola. African Journal of Marine Science 28:713-717

Sinclair I (2007) First record of Bob-tailed Weaver Brachycope anomala for Angola. Bulletin of the African Bird Club 14:78-78

Sinclair I, Chamberlain D, Chamberlain M, et al. (2007) Observations of three littleknown bird species in northern Angola. Bulletin of the African Bird Club 14:55-56

Sinclair I, Spottiswoode CN, Cohen C, et al. (2004) Birding western Angola. Bulletin of the African Bird Club 16:211-212

Steinheimer FD, Dean WRJ (2007) Avian type specimens and their type localities from Otto Schütt's and Friedrich von Mechow's Angolan collections in the Museum für Naturkunde of the Humboldt-University of Berlin. Zootaxa 1387:1-25

Stjernstedt R, Aspinwall DR (1979) The nest and eggs of the Bar-winged Weaver Ploceus angolensis. Bulletin of the British Ornithologists' Club 99:138-140

Tye A (1992) A new subspecies of Cisticola bulliens from northern Angola. Bulletin of the British Ornithologists' Club 112:55-56 


\section{References}

Bamford AJ, Diekmann M, Monadjem A et al (2007) Ranging behaviour of Cape Vultures Gyps coprotheres from an endangered population in Namibia. Bird Conserv Int 17:331-339

Bannerman DA (1912) On a collection of birds made by Mr Willoughby P. Lowe on the West Coast of Africa and outlying islands; with field notes by the collectors. Ibis 54:219-229

Baptista NL, Mills MSL (2018) Angola White-headed Barbet Lybius [leucocephalus] leucogaster rediscovered. Bull Afr Bird Club 25:225-229

BirdLife International (2017) Endemic bird areas factsheet: Western Angola. Downloaded from http://www.birdlife.org on 19/04/2017

Bocage JVB du (1877) Ornithologie d'Angola. Part 1. Imprimerie Nationale, Lisbonne (Lisbon), pp $1-256$

Bocage JVB du (1881) Ornithologie d'Angola. Part 2. Imprimerie Nationale, Lisbonne (Lisbon), pp 257-576

Boulton R (1931) New species and subspecies of African birds. Ann Carnegie Museum 21:43-56

Bowen WW (1931) Angolan birds collected during the Gray African expedition - 1929. Proc Acad Natl Sci Phila 83:263-299

Bowen WW (1932) Angolan birds collected during the second Gray African expedition - 1930. Proc Acad Natl Sci Phila 84:281-289

Bowie RCK, Fjeldsa J, Kiure J et al (2016) A new member of the greater double-collared sunbird complex (Passeriformes: Nectariniidae) from the Eastern Arc Mountains of Africa. Zootaxa 4175:23-42

Braun R (1930) Beitrage zur Biologie der Vögel von Angola. J Ornithol 78:47-49

Braun R (1934) Biologische Notizen über einige Vögel Nord-Angolas. J Ornithol 82:553-560

Büttikofer J (1888) On birds from the Congo and South Western Africa. Notes Leyden Mus 10:209-244

Büttikofer J (1889a) On a new collection of birds from South Western Africa. Notes Leyden Mus 11:65-79

Büttikofer J (1889b) Third list of birds from South Western Africa. Notes Leyden Mus 11:193-200

Cáceres A (2011) Implementation of eco-tourism as a conservation tool to save the last remnants of Afromontane Forest of Mount Moco, Angola. MSc thesis. University of Porto, Porto

Cáceres A, Melo M, Barlow J et al (2015) Threatened birds of the Angolan Central Escarpment: distribution and response to habitat change at Kumbira Forest. Oryx 49:727-734

Cáceres A, Melo M, Barlow J et al (2016) Radio telemetry reveals key data for the conservation of Sheppardia gabela (Rand, 1957) in the Angolan Escarpment Forest. Afr J Ecol 54:317-327

Cáceres A, Melo M, Barlow J et al (2017) Drivers of bird diversity in an understudied African centre of endemism: the Angolan Escarpment Forest. Bird Conserv Int 27:256-268

Dean WRJ (1974) Breeding and distributional notes on some birds of Angola. Durban Mus Novit 10:109-125

Dean WRJ (1996) The distribution of the Masked Weaver Ploceus velatus in Angola. Bull Br Ornithol Club 116:254-256

Dean WRJ (2000) The birds of Angola: an annotated checklist. BOU Checklist No. 18. British Ornithologists' Union, Tring

Dean WRJ (2001) Angola. In: Evans MI (ed) Fishpool LDC. Important Bird Areas in Africa and Associated Islands - Priority Sites for Conservation. BirdLife International, Cambridge \& Pisces Publications, Newbury

Dean WRJ, Le Maitre DC (2008) The birds of the Soyo area, Northwest Angola. Malimbus 30:1-18

Dean WRJ, Dowsett RJ, Sakko A et al (2002) New records and amendments to the birds of Angola. Bull Br Ornithol Club 122:180-184

Dean WRJ, Irwin MPS, Pearson DJ (2003) An isolated population of Singing Cisticola, Cisticola cantans, in Angola. Ostrich 74:231-232

Dowsett RJ, Aspinwall DR, Dowsett-Lemaire F (2008) The birds of Zambia. An atlas and handbook. Tauraco Press and Aves, Liège 
Fuchs J, Crowe TM, Bowie RCK (2011) Phylogeography of the fiscal shrike (Lanius collaris): a novel pattern of genetic structure across the arid zones and savannas of Africa. J Biogeogr 38:2210-2222

Günther R, Feiler A (1986a) Zur phänologie, ökologie und morphologie angolanischer Vögel (Aves). Teil I: Non-Passeriformes. Faunistische Abhandlungen aus dem Staatlichen Museum für Tierkunde in Dresden 13:189-227

Günther R, Feiler A (1986b) Zur phänologie, ökologie und morphologie angolanischer Vögel (Aves). Teil II: Passeriformes. Faunistische Abhandlungen aus dem Staatlichen Museum für Tierkunde in Dresden 14:1-29

Hall BP (1960a) The faunistic importance of the scarp of Angola. Ibis 102:420-442

Hall BP (1960b) The ecology and taxonomy of some Angolan birds. Bull Brit Mus (Nat Hist) Zool 6:367-463

Hartlaub G (1865) Descriptions of seven new species of birds discovered by Mr J. J. Monteiro in the Province of Benguela, Angola, West Africa. Proc Zool Soc London 33:86-88

Hartlaub G, Monteiro JJ (1860) On some birds collected in Angola. Proc Zool Soc London 28:109-112

Hawkins F (1993) An integrated biodiversity conservation project under development: the ICBP Angola Scarp Project. Proceedings of the VIII Pan-African Ornithological Congress: 279-284. Kigali, Rwanda, 1992. Koninklijk Museum voor Midden-Afrika, Tervuren

HBW and BirdLife International (2017) Handbook of the Birds of the World and BirdLife International digital checklist of the birds of the world. Version 2. Available at: http://datazone. birdlife.org

Heinrich G (1958a) Zur Verbreitung und Lebensweise der Vögel von Angola. J Ornithol 99:121-141

Heinrich G (1958b) Zur Verbreitung und Lebensweise der Vögel von Angola. Systematischer Teil I (Galli - Muscicapidae). J Ornithol 99:322-362

Heinrich G (1958c) Zur Verbreitung und Lebensweise der Vögel von Angola. Systematischer Teil III (Hirundinidae - Fringillidae). Journal für Ornitholgie 99:399-421

Huntley BJ, Matos EM (1994) Botanical diversity and its conservation in Angola. Strelitzia $1: 53-74$

Irwin MPS (1991) The specific characters of the Slender-tailed Cisticola Cisticola melanura (Cabanis). Bull Br Ornithol Club 111:228-236

Jones PJ, Tye A (2006) The Birds of São Tomé and Príncipe, with Annobón: Islands of the Gulf of Guinea. BOU Checklist No. 22. British Ornithologists' Union \& British Ornithologists' Club, Oxford

Lambert K (2001) Sightings of new and rarely reported seabirds in Southern African waters. Mar Ornithol 29:115-118

Leite A, Cáceres A, Melo M, Mills MSL, Monteiro AT (2018) Reducing Emissions from Deforestation and forest Degradation (REDD+) in Angola: insights from the Scarp Forest conservation hotspot. Land Degrad Dev 29:4291-4300. https://doi.org/10.1002/ldr.3178

Louette M (1984) The identity of swamp-dwelling weavers in North-East Angola. Bull Br Ornithol Club 104:22-24

Louette M, Benson CW (1982) Swamp-dwelling weavers of the Ploceus velatus/vitellinus complex, with the description of a new species. Bull Br Ornithol Club 102:24-31

Lundevall C-F, Ängermark W (1989) Fåglar från Namibia. Axel W. Erikssons fågelsamling från Sydvästafrika på Vänersborg Museum. Älvsborgs Länsmuseum, Vänersborg

Lynes H (1938) Contribution to the ornithology of the Southern Congo Basin. Revue de Zoologie et Botanique Africaines 31:3-128

Lynes H, Sclater WL (1933) Lynes-Vincent tour in Central and West Africa in 1930-1931. Part I. Ibis 75:694-729

Lynes H, Sclater WL (1934) Lynes-Vincent tour in Central and West Africa in 1930-1931. Part II. Ibis $76: 1-51$

Meise W (1958) Über neue Hühner-, Specht- und Singvögelrassen von Angola. Abhandlungen des Naturwissenschaftlichen Vereins in Hamburg, N.F. 2:63-83 
Ménégaux A, Berlioz J (1923) Oiseaux. In: Mission Rohan-Chabot: Angola et Rhodesia (19121914). Tome IV: Histoire Naturelle. Fascicle 1: Mammifères (anatomie comparée, embryologie). Oiseaux. Reptiles. Poissons. Imprimerie Nationale, Paris, pp 107-155

Meyburg B-U, Ellis DH, Meyburg C et al (2001) Satellite tracking of two lesser spotted eagles, Aquila pomarina, migrating from Namibia. Ostrich 72:35-40

Mills MSL (2006) First record of Pink-billed Lark Spizocorys conirostris for Angola. Bull Afr Bird Club 13:212

Mills MSL (2010) Angola's central scarp forests: patterns of bird diversity and conservation threats. Biodivers Conserv 19:1883-1903

Mills MSL (2013) Little-known African bird: Bocage's Sunbird Nectarinia bocagii—an Angolan near-endemic. Bull Afr Bird Club 20:80-88

Mills MSL (2015) First record of Pacific Golden Plover Pluvialis fulva for Angola. Bull Afr Bird Club 22:223-224

Mills MSL (2018) The Special Birds of Angola/As Aves Especiais de Angola. Go-away-birding, Cape Town \& Kissama Foundation, Luanda

Mills MSL, Cohen C (2007) Brazza's Martin Phedina brazzae: new information on range and vocalisations. Ostrich 78:51-54

Mills MSL, Dean WRJ (2007) Notes on Angolan birds: new country records, range extensions and taxonomic questions. Ostrich 78:55-63

Mills MSL, Dean WRJ (2013) The avifauna of the Lagoa Carumbo area, Northeast Angola. Malimbus 35:77-92

Mills MSL, Dowd AD (2007) First records of Lemon Dove Aplopelia larvata for Angola. Bull Afr Bird Club 14:77-78

Mills MSL, Melo M (2013) The checklist of the birds of Angola/A Lista das Aves de Angola. Associação Angolana para Aves e Natureza \& Birds Angola, Luanda

Mills MSL, Melo M (2015) As Aves Comuns de Luanda/The Common Birds of Luanda. Associação Aves e Natureza Angola, Luanda

Mills MSL, Tebb G (2015) First record of forest swallow Petrochelidon fuliginosa for Angola. Bull Afr Bird Club 22:221-222

Mills MSL, Vaz A (2011) The nest and eggs of Margaret's Batis Batis margaritae. Bull Br Ornithol Club 131:208-210

Mills MSL, Vaz Pinto P (2015) An overlooked population of White-collared Oliveback Nesocharis ansorgei, in Angola. Bull Afr Bird Club 22:64-67

Mills MSL, Cohen C, Spottiswoode C (2004) Little-known African bird: Gabela Akalat, Angola's long-neglected Gabelatrix. Bull Afr Bird Club 11:149-151

Mills MSL, Vaz Pinto P, Dean WRJ (2008) The avifauna of Cangandala National Park, Angola. Bull Afr Bird Club 15:113-116

Mills MSL, Franke U, Joseph G et al (2010) Cataloguing the Lubango Bird Skin Collection: towards an atlas of Angolan bird distributions. Bull Afr Bird Club 17:43-53

Mills MSL, Melo M, Vaz A (2011a) Black-tailed Cisticola Cisticola melanurus in eastern Angola: behavioural notes and the first photographs and sound recordings. Bull Afr Bird Club 18:193-198

Mills MSL, Olmos F, Melo M et al (2011b) Mount Moco: its importance to the conservation of Swierstra's Francolin Pternistis swierstrai and the Afromontane avifauna of Angola. Bird Conserv Int 21:119-133

Mills MSL, Melo M, Vaz A (2013a) The Namba mountains: new hope for Afromontane forest birds in Angola. Bird Conserv Int 23:159-167

Mills MSL, Vaz Pinto P, Palmerim JM (2013b) First records for Angola of Yellow-throated Cuckoo Chrysococcyx flavigularis, South African Cliff Swallow Petrochelidon spilodera and Redtailed Leaflove Phyllastrephus scandens. Bull Afr Bird Club 20:200-204

Mills MSL, Bennett B, Baptista N et al (2016) Red-necked Falcon Falco chicquera in Angola. Bull Afr Bird Club 23:89-90 
Moltoni E (1932) Uccelli d'Angola raccolti da L. Fenaroli durante la spedizione 1930 BaragioliDurini. Atti della Società Italiana di Scienze Naturali e del Museo Civico di Storia Naturale in Milano 71:169-178

Monard A (1932) Matériaux de la mission scientifique suisse en Angola. Oiseaux. Bull Soc Neuchâteloise Sci Nat 56:301-355

Monard A (1934) Ornithologie de l'Angola. Arquivos do Museu Bocage 5:1-110

Monteiro M, Reino L, Beja P et al (2014) The collection and database of birds of Angola hosted at IICT (Instituto de Investigação Científica Tropical), Lisboa, Portugal. ZooKeys 387:89-99

Pinto AA da R (1972) Contribuição para o estudo da avifauna do Distrito de Cabinda (Angola). Memórias e Trabalhos do Instituto de Investigação Científica de Angola 10:1-103

Pinto AA da R (1983) Ornitologia de Angola, vol 1. Instituto de Investigacão Cientifica Tropical, Lisboa

Rudebeck G (1955) Aves I. S Afr Anim Life 2:426-576

Rudebeck G (1958) A new race of the Bunting Fringillaria capensis (L.) from Angola. Bull Br Ornithol Club 78:129-132

Ryan PG, Sinclair I, Cohen C et al (2004) The conservation status and vocalizations of threatened birds from the scarp forests of the Western Angola Endemic Bird Area. Bird Conserv Int $14: 247-260$

Seabra A (1905a) Aves de Angola da exploração de F. Newton. J Sci Math Phys Nat 7(26):118-128

Seabra A (1905b) Mammiferos e aves da exploração de F. Newton em Angola. J Sci Math Phys Nat 7(26): 103-110

Seabra A (1906a) Aves da exploração de Fr. Newton em Angola - Subsidios para o conhecimento da destribuição geographica das aves d'Africa occidental. Ann Sci Nat 10:153-159

Seabra A (1906b) Aves de Porto Alexandre. J Sci Math Phys Nat 7(27):143-148

Seabra A (1906c) Nota sobre a existencia de "Diomedia imutabilis" nas costas occidentaes de Africa. J Sci Math Phys Nat 7(27):141-142

Seabra A (1906d) Ribeirinhas e palmípedes das margens do Rio Cunene. Ann Sci Nat 10:83-90

Seabra A (1907) Sur quelques oiseaux d'Angola envoyés par Francisco Newton. Contribution à l'étude de la distribution géographique des oiseaux de l'Afrique occidentale. Bull Soc Portugaise Sci Naturelles 1:41-45

Sekercioğlu CH, Riley A (2005) A brief survey of the birds in Kumbira Forest, Gabela, Angola. Ostrich 76:111-117

Serle W (1955) The bird life of the Angolan littoral. Ibis 97:425-431

Sharpe RB (1871) On the birds of Angola.-Part III. Proc Zool Soc London 39:130-135

Sharpe RB, Bouvier A (1876a) Catalogue d'une collection recueille à Lândana et Chinchoxo (Congo), par M. Louis Petit, pendant les mois de janvier février, mars et avril 1876. Bull Soc Zool Fr 1:36-53

Sharpe RB, Bouvier A (1876b) Sur les collections recueilles dans la région du Congo par MM. le Dr A. Lucan et L. Petit, depuis le mois de mai jusqu'en septembre. Bull Soc Zool Fr 1:300-314

Sharpe RB, Bouvier A (1877) Nouvelle liste d'oiseaux recueillis dans la région du Congo par MM. le Dr A. Lucan et L. Petit, de Septembre 1876 à Septembre 1877. Bull Soc Zool Fr 2:470-481

Sharpe RB, Bouvier A (1878) Nouvelle liste d'oiseaux recueillis dans la région du Congo par MM. le Dr A. Lucan et L. Petit, de Septembre 1876 à Septembre 1877. Bull Soc Zool Fr 3:73-80

Sharpe RB, Monteiro JJ (1869) On the birds of Angola.-Part I. Proc Zool Soc London 37:563-571

Sick H (1934) Ueber einige Vogelbälge aus Nord-Angola, gesammelt von Herrn R. Braun. Ornithol Monatsberichte 42:167-172

Simmons RE, Mills MSL, Dean WRJ (2009) Oystercatcher Haematopus records from Angola. Bull Afr Bird Club 16:211-212

Sinclair JC (1981) First sight records of the Booted Eagle in Angola. Ostrich 52:57

Stavrou C, Mills MSL (2013) Observations of birds of the Soyo area, Northwest Angola. Malimbus 35:27-36

Stresemann E (1934) Apalis rufogularis brauni subsp. nov. Ornith Monatsber 62:156-157 
Stresemann E (1937) Weitere Vogelbälge aus Nord-Angola, gesammelt von Herrn R. Braun. Ornithol Monatsberichte 45:51-53

Swanepoel W (2013) Rock star. Angola cave chat: a new species for Namibia. Afr Birdlife 1:30-32 Tobias JA, Seddon N, Spottiswoode CN et al (2010) Quantitative criteria for species delimitation. Ibis $152: 724-746$

Traylor MA (1963) Check-list of Angolan Birds. Publicações Culturais 6. Companhia de Diamantes de Angola (DIAMANG), Lisboa

Vaz da Silva B (2015) Evolutionary history of the birds of the Angolan Highlands - the missing piece to understand biogeography of the Afromontane Forests. MSc thesis. University of Porto, Porto

Vaz Pinto P (2002) Field notes on the Grey-striped Francolin (Francolinus griseostriatus) in w Angola. Newsletter of the Partridge, Quail and Francolin Specialist Group 17:3-5

White CMN (1950) Some records from Eastern Angola. Bull Br Ornithol Club 70:35

White F (1978) The Afromontane region. In: Werger MJA (ed) Biogeography and ecology of Southern Africa. Springer, Dordrecht, pp 463-513

Open Access This chapter is licensed under the terms of the Creative Commons Attribution 4.0 International License (http://creativecommons.org/licenses/by/4.0/), which permits use, sharing, adaptation, distribution and reproduction in any medium or format, as long as you give appropriate credit to the original author(s) and the source, provide a link to the Creative Commons licence and indicate if changes were made.

The images or other third party material in this chapter are included in the chapter's Creative Commons licence, unless indicated otherwise in a credit line to the material. If material is not included in the chapter's Creative Commons licence and your intended use is not permitted by statutory regulation or exceeds the permitted use, you will need to obtain permission directly from the copyright holder.

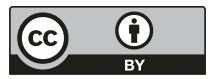

